\title{
PENGEMBANGAN SUMBER DAYA MANUSIA DI ERA MILENIAL MEMBENTUK MANUSIA BERMARTABAT
}

\author{
${ }^{1}$ Sony Eko Adisaputro, ${ }^{2}$ Imam Rosidi \\ ${ }^{1}$ IAI Pangeran Diponegoro Nganjuk, ${ }^{2}$ IAI Pangeran Diponegoro Nganjuk \\ ${ }^{1}$ sonyeko@iaipd-nganjuk.ac.id, ${ }^{2}$ imamrosidi@iaipd-nganjuk.ac.id
}

\begin{abstract}
ABSTRAK
Negara yang unggul dalam penguasaan ilmu pengetahuan dan teknologi akan dapat mengambil manfaat besar dari proses ini.keunggulan dalam penguasaan iptek ini dapat dicapai terutama dengan peningkatan kualitas SDM yang peka serta mampu memanfaatkan berbagai peluang. Adanya pengembangan kualitas manusia juga dapat memperkokoh pemahaman dan keimanan agama Islam, bisa juga dengan meningkatkan ilmu pengetahuan dan teknologi yang dimiliki. Penguasaan iptek oleh umat Islam (salah satu aspek yang sangat menentukan kebesaran dan kemajuan suatu bangsa atau umat), dimaksudkan agar umat Islam bisa berperan di tengah-tengah kemajuan peradaban itu. Martabat suatu bangsa itu bergantung pada akhlaknya. Jika akhlaknya rusak, maka rusak binasa pulalah bangsa itu, hal ini menunjukkan bahwa akhlak hendaknya selalu menjadi landasan bagi kehidupan manusia. Sebab kalau tidak demikian, maka kehancuran itu menimpa, baik bagi generasi sekarang maupun generasi yang akan datang. Metode penelitiannya adalah studi kepustakaan (Library Research) yaitu studi kepustakaan. Metode pengumpulan data yang digunakan dalam kajian ini adalah metode dokumentasi. Teknik analisa data yang digunakan content analysis adalah metodologi penelitian dari sebuah dokumen. Kajian isi adalah teknik penelitian yang dimanfaatkan untuk menarik kesimpulan yang replikatif dan sahih dari data atas dasar konteksnya. Hasil penelitiannya adalah 1) peningkatan sumber daya manusia mendapatkan perhatian yang sangat besar, karena merupakan persyaratan untuk memacu pembangunan. Manusia dalam pandangan Islam merupakan makhluk unggulan, yang membekali beberapa potensi, yaitu jasmani (fisik), potensi nalar (akal/ratio), potensi hati nurani (qalbu). Kualitas SDM pada intinya terletak pada kualitas ilmu dan akhlak, yang ditopang dengan kualitas ketrampilan yang memadai. Untuk dapat mencapai kualitas sumber daya manusia yang berkualitas dan dapat berkembang secara maksimal harus ada pembinaan melalui pendidikan baik itu pendidikan formal, informal, non formal. 2) Pengembangan kualitas manusia dengan jalan mengembangkan potensi-potensi atau sumber daya yang ada pada diri manusia agar dapat menjadi manusia yang dalam arti sesungguhnya. Pengembangan kualitas manusia itu bisa dengan memperkokoh pemahaman dan keimanan agama Islam, bisa juga dengan meningkatkan ilmu pengetahuan dan teknologi yang dimiliki. Penguasaan iptek oleh umat Islam (salah satu aspek yang sangat menentukan kebesaran dan kemajuan suatu bangsa atau umat), dimaksudkan agar umat Islam bisa berperan di tengah-tengah.
\end{abstract}

\section{Kata Kunci: Sumber Daya Manusia, Globalisasi, Bangsa, Martabat}

\section{PENDAHULUAN}

Globalisasi merupakan fenomena dua dasawarsa belakangan ini, yang dipicu oleh kemajuan teknologi transformasi dan kemajuan ekonomi atau industrialisasi. Ia datang menembus batas-batas kedaulatan nasional setiap negara, baik itu negara maju apalagi negaranegara sedang berkembang. Arus globalisasi ini datangnya begitu cepat, kuat dan kerapkali radikal. Pengaruh dari arus globalisasi ini menyentuh hampir semua bidang kehidupan; mulai dari yang bersifat material seperti barang-barang konsumsi, pakaian, alat transportasi dan komunikasi; dan yang bersifat keilmuan seperti konsep keilmuan, teori dan metodologi sampai 
teknologi dan paradigma keilmuan; yang bersifat moral dan etis seperti pergaulan bebas, lemahnya disiplin moral, longgarnya norma susila dan bersifat sosial seperti lemahnya peranan keluarga, bergesernya nilai hubungan sosial, perekayasaan perilaku sosial dan lain-lain.

Arus perubahan yang dibawa oleh globalisasi membawa dampak langsung terhadap perjalanan historis manusia. Menurut Nur Cholis Majid, yang pertama bisa dirasakan adalah dampak yang bersifat psikologi. Bagaimana peralihan dari satu abad ke abad yang lain mempunyai dampak kejiwaan tersendiri bagi kebanyakan masyarakat. Dampak lain arus globalisasi bersifat spekulatif, diantara positif dan negatif. Dampak positif globalisasi membawa kemajuan seluruh negara disegala sektor, terutama transportasi, telekomunikasi, dan informasi. Disisi lain globalisasi membawa dampak negatif jauh lebih besar, karena tidak semua bangsa mampu menerimanya. Bahkan bangsa-bangsa yang lebih dulu menciptakan infrastruktur modernisasi dan globalisasi belum tentu siap menerima arus balik ini. Bahkan dalam beberapa hal umat Islam banyak dirugikan oleh arus globalisasi. Dalam kondisi demikian, harus diakui bahwa bangsa Indonesia masih menghadapi masalah mendasar dalam hal kualitas sumber daya manusia. Secara umum, kehidupan masyarakat kita masih diliputi oleh lemahnya kualitas pengalaman disiplin nasional dan etos nasional. Hal ini bisa ditunjukkan, umpamanya, oleh rendahnya penghargaan terhadap waktu, lemahnya penghayatan nilai kualitas prestasi, serta penghayatan terhadap norma-norma hukum.

Dalam hal ini, seorang manusia modern yang maju adalah yang cenderung merealisasikan segala cita, rasa dan karsanya ke dalam karya nyata, dan kemudian senantiasa cenderung untuk meningkatkan karya nyatanya itu menjadi karya terbaik atau prestasi, dalam proses dinamis dan sistematis untuk menghampiri cita-cita (tujuan hidup), sebagai manifestasi dari penghadapan kemasa depan. Dalam perspektif di atas, manusia dan masyarakat modern memiliki beberapa kecenderungan, antara lain: (1). Bersifat rasional dalam menghadapi segala hal, yaitu dapat memberikan pertimbangan yang logis dalam menentukan pilihan, (2). Bersifat terbuka (outward looking), yaitu toleran, apresiatif dan akomodatif terhadap perkembangan diluar dirinya yang dinilai mengandung kebaikan, dan (3). Disiplin terhadap waktu, yaitu kecenderungan untuk mengisi dan memanfaatkan waktu dengan sebaik-baiknya. Disiplin waktu ini melahirkan kecenderungan dengan menampilkan hidup yang berencana dengan perencanaan strategis dan berorientasi pada efisiensi dan efektivitas kerja.

Orang-orang barat melihat betapa dunia ini telah porak poranda, akibat menggilanya penggunaan tekhnologi. Manusia menjadi semakin mekanik, iptek dan tekhnologi yang semula 
$\int \begin{aligned} & \text { p-ISSN: 2723-4703 } \\ & \text { e-ISSN: - } \\ & \text { http://ejurnal.iaipd-nganjuk.ac.id/index.php/j-kis/ } \\ & \text { KURNALUNIKASI ISLAM }\end{aligned}$

diciptakan manusia untuk menundukkan dunia, justru menciptakan berbagai bentuk kegalauan hidup, berbagai potologi kehidupan modern menjadi kian menjadi-jadi. Kecenderungan inilah yang seringkali membuat banyak orang mencari tempat pelarian, hal ini terlihat semakin maraknya kelompok-kelompok spiritual yang menawarkan ketenangan psikologis dan bahkan muncul dalam bentuk-bentuk yang kurang positif semisal, munculnya banyak bentuk radikalisasi agama. Untuk mengantisipasi perubahan zaman yang semakin modern maka perubahan dari meningkatnya ilmu dan tehnologi mendorong manusia untuk berlomba-lomba meningkatkan prestasi sumber daya yang dimilikinya agar mampu untuk meningkatkan potensi sumber daya yang dimilikinya, sehingga dapat digunakan secara efektif dan efisien untuk mencapai suatu kajian tertentu.

Dalam perjalanan memasuki abad ke-21, era millenium ketiga, kesadaran global tentang peningkatan kualitas sumber daya manusia melalui pendidikan dan kehendak untuk menempatkan manusia sebagai titik sentral pembangunan (human centred development) tampak semakin jelas, dan pendidikan pada dasarnya merupakan usaha pengembangan sumber daya manusia, yang dilakukan secara sistematis, programatis dan berjenjang, agar dapat dihasilkan manusia-manusia yang berkualitas, yang akan dapat memberikan manfaat dan sekaligus meningkatkan harkat dan martabatnya. Dan juga dapat menumbuhkan kepribadian yang religius dan berakhlakul karimah sehingga kualitas diri diimbangi dengan ketahanan mental dan kemauan spiritual yang handal.

Abuddin Nata, menulis bahwa pendidikan agama diartikan pendidikan yang materi bahasannya berkaitan dengan keimanan, ketaqwaan, akhlak, dan ibadah kepada Tuhan. Dengan demikian pendidikan agama berkaitan dengan pembinaan sikap mental spiritual yang selanjutnya dapat mendasari tingkah laku manusia dalam berbagai bidang kehidupan.

Dititik inilah seharusnya umat islam hendaknya mampu membaca kecenderungan keadaan sehingga mampu mengambil terobosan pemikiran yang mampu menghadirkan suasana baru. Dalam hal ini umat islam melalui pendidikan harus mengembangkan sumber daya manusianya. Hal ini disebaban karena pendidikan merupaka alat yang fungsional dalam upaya pembentukan manusia yang berkualitas, yang mampu mandiri dan memberikan dukungan bagi perkembangan masyarakat, dan dan berpengaruh dalam peningkatan mutu kehidupan dan mengangkat martabat bangsa. 


\section{METODE PENELITIAN}

Penelitian ini termasuk dalam jenis penelitian teoritis yaitu studi kepustakaan (Library Research) yaitu studi kepustakaan. Hal ini dimaksudkan untuk menghimpun data dan informasi lain yang mempunyai kaitan dengan topik penelitian ini. Kajian pustaka yaitu penampilan argumentasi penalaran keilmuan yang memaparkan hasil penelitian pustaka dan hasil pemikiran peneliti mengenai suatu masalah (topik), hasil kajian pustaka semacam ini berisi satu topik yang didalamnya memuat beberapa gagasan dan informasi dari sumber pustaka (literature), bahanbahan pustaka yang dipakai harus dibahas secara kritis dan mendalam dalam rangka mendukung gagasan atau proposisi untuk menghasilkam kesimpulan dan saran. Dari istilah diatas dapat dikatakan pula bahwa penelitian ini merupakan penelitian yang lebih berorientasi pada penggalian data, atau tepatnya referensi yang berasal dari karya ilmiah, atau karya tulis yang sudah ada sebelumnya.

Sumber data adalah subyek dari mana data dapat diperoleh, sumber data ini meliputi data primer dan data sekunder : 1) Sumber Data Primer yaitu bahan pustaka yang berisikan pengetahuan ilmiah yang baru atau mutakhir, ataupun pengertian baru tentang fakta yang diketahui maupun mengenai gagasan (ide). Adapun sumber primer yang digunakan dalam penelitian ini yang digunakan adalah buku, jurnal ilmiah, buletin dan sebagainya. 2) Sumber Data Sekunder yaitu bahan pustaka/sumber data sebagai penunjang dalam skripsi ini, seperti semua buku yang ada hubungannya dengan judul skripsi ini secara tidak langsung.

Metode dan instrumen pengumpulan data yang digunakan dalam kajian ini adalah metode dokumentasi yaitu cara pencarian data dari hal-hal yang akan dibahas ataupun teori-teori yang akan digunakan dalam rumusan data yang kemudian disimpulkan. Data ini dapat berupa transkip, cacatan, majalah, prasasti, dan sebagainya.

Teknik analisa data yang digunakan yaitu content analysis yaitu metode yang lebih mengedepankan pada pengungkapan aspek isi (esensi) dari beberapa proposisi yang ada. Lebih lanjut metode ini merupakan watak dari peninjauan berbagai teori dan analisis. Kajian isi sebagai teknik penelitian untuk keperluan mendeskripsikan secara obyektif, sistematis dan kuantitatif tentang manifestasi komunikasi. Weber yang dikutip oleh Soejono dan Abdurrahman menyatakan bahwa content analysis adalah metodologi penelitian dari sebuah dokumen.Kajian isi adalah teknik penelitian yang dimanfaatkan untuk menarik kesimpulan yang replikatif dan sahih dari data atas dasar konteksnya. 
$\int \begin{aligned} & \text { p-ISSN: 2723-4703 } \\ & \text { e-ISSN: - } \\ & \text { http://ejurnal.iaipd-nganjuk.ac.id/index.php/j-kis/ } \\ & \text { KURNAL }\end{aligned}$

\section{HASIL DAN PEMBAHASAN}

\section{Sumber Daya Manusia}

Sumber daya manusia adalah kemampuan terpadu dari daya pikir dan daya fisik yang dimiliki individu. Daya fikir merupakan kecerdasan yang dibawa sejak lahir (modal dasar). Sedangkan kecakapan diperoleh dari usaha (belajar dan pelatihan) atau mengikuti pendidikan. Sedangkan kecerdasan tolok ukurnya adalah kemampuannya dalam menyelesaikan persoalan yang dihadapi yang diukur lewat Intelegence Quotient (IQ). Kecerdasan dan kecakapan individu diimplementasikan untuk menciptakan ide-ide, inovasi, kreativitas, dan kecakapannya dalam bidang yang ditekuninya. Hasan Langgulung menyatakan bahwa Sumber daya manusia adalah bagian atau porsi penduduk produktif yang eksis dalam suatu masyarakat. Ada pula penulis yang mengatakan kata "sumber daya manusia" itu adalah bagian atau porsi penduduk produktif eksis dalam suatu masyarakat. Tetapi dengan segera ia menyebutkan bahwa porsi kuantitatif pada sumber daya manusia adalah jumlah penduduk dalam umur 15-65 tahun itu, dan juga tidak usah dipahami sebagai orang-orang yang bekerja dipabrik atau instansi tertentu, karena proses yang memberi input dan menghasilkan output dapat disebut produksi, dimana saja dan siapa saja yang mengerjakannya.

Menurut Wardiman Djojonegoro manusia yang berkualitas adalah manusia yang minimal memiliki kompetensi dalam ilmu pengetahuan (IPTEK), dan kompetensi dalam keimanan dan ketaqwaan kepada Allah SWT. Kompetensi ilmu pengetahuan dan teknologi termasuk kemampuan untuk menghadapi perubahan mencakup, kemampuan memahami hakekat, perubahan dan kemampuan mengelola perubahan sehingga dapat mengambil manfaat dari perubahan tersebut, yaitu menampilkan keunggulan melalui prestasi nyata dalam berbagai bidang kehidupan.

Dalam kehidupan yang serba teknologis ini, manusia dapat mengalami alienasi, manusia tidak lagi hidup secara langsung bebas dengan alam lingkungannya, hidup secara berangsurangsur dikelilingi oleh teknologi, organisasi dan sistem yang diciptakannya sendiri. Memang berkat ilmu pengetahuan dan teknologi, manusia dapat bangkit dari tekanan berat alam yang selalu mengganggunya, akan tetapi secara sistematis mulai tergantung pada hasil ciptaannya dan organisasinya. Dominasi alam dapat dilepaskan, tetapi teknologi dan birokrasinya bangkit dengan dominasi dan kekuatannya yang dahsyat menguasai manusia dan menjadikannya tergantung dan lemah. Alat benar-benar menjadi tuan, sebaliknya manusia adalah hamba yang 
mengekor, dan merupakan bahaya yang besar manakala ilmu pengetahuan dianggap sebagai satu-satunya metode bagi manusia, sedang wahyu dan firman Allah swt, dinomer duakan atau bahkan dihilangkan dan hancur oleh manusia-manusia yang lupa dengan khaliqnya dan hanya berfikir soal-soal IPTEK. Ilmu pengetahuan pada hakekatnya harus berhubungan erat dengan moralitas manusia, sebab manusia yang mempunyai pengetahuan luas tanpa didasari oleh nilainilai moral dan agama dapat menjadi sombong dan lupa diri.

Dengan demikian peran dari kompetensi iman dan taqwa (IMTAQ) amat penting karena tanpa dibingkai oleh iman dan taqwa, maka kompetensi ilmu pengetahuan dan teknologi akan menjadi kurang bermakna, bahkan dikhawatirkan akan liar dan tidak terkendali yang mewujud dalam bentuk terjadinya erosi nilai-nilai moral. Dipihak lain kompetensi imam dan taqwa tanpa disertai kompetensi ilmu pengetahuan dan teknologi, akan lemah dan tidak berdaya. Sebagai komponen mayoritas bangsa dituntut untuk memiliki dua kompetensi tersebut secara seimbang.

Spiritual manusia yang bersumber pada keimanan dan ketaqwaan, memberikan beberapa macam kesadaran dalam eksistensinya yaitu kesadaran akan hidupnya yang terbatas, kesadaran akan pencarian makna hidup, kesadaran akan pendayagunaan nikmat dan mensyukurinya dan kesadaran akan kemungkinan terjadinya kelalaian karena terkecoh godaan. Dengan kesadarankesadaran tersebut manusia akan mengetahui kualitas yang ada pada diri yang kemudian menggali segala potensi yang dimilikinya dikemudian hari. Dengan demikian sumber daya manusia (manusia berkualitas) merupakan hal yang sangat penting yang harus dimiliki manusia, tidak hanya dilingkungan industri atau perusahaan tetapi juga organisasi diberbagai bidang baik politik pemerintahan, hukum, sosial budaya, lingkungan dan sebagainya.

Manusia produktif adalah manusia yang realistik dalam menyikapi lingkungannya. Dia sadar akan potensi-potensi yang ada, akan kekurangan-kekurangan serta keterbatasanketerbatasan yang dihadapinya, memahami persoalan dan kebutuhan zamannya. Dengan demikian, Ia mampu menangkap kemungkinan-kemungkinan yang terbentang didepannya. Jadi manusia produktif mempunyai kemampuan diri yang dapat berguna dalam memberikan sesuatu terhadap dirinya maupun terhadap orang lain baik dari segi pemikiran atau hasil karyanya untuk kemakmuran dan kesejahteraannya. Contohnya seorang ibu rumah tangga itu produktif, sebab ia mengerjakan pekerjaan rumah tangga yang nilainya sama atau lebih baik dari hasil kerja yang dihasilkan oleh pembantu rumah. Malah seorang anak kecilpun dapat dianggap produktif terhadap ibu dan ayahnya sebab ia dapat memberikan kebahagiaan pada diri yang pada gilirannya bisa menambah semangat kerja pada ibu dan ayahnya, sebab mendapat kebahagiaan 
$\int \begin{aligned} & \text { p-ISSN: } 2723-4703 \\ & \text { e-ISSN: - } \\ & \text { http://ejurnal.iaipd-nganjuk.ac.id/index.php/j-kis/ } \\ & \text { KURNALUNIKASI ISLAM }\end{aligned}$

yang disebabkan olehnya. Pendeknya semua orang itu produktif, kecil ataupun besar, lelaki atau perempuan, terdidik atau tidak terdidik, masing-masing memiliki cara untuk memberi input dan output dalam konteks yang menyeluruh.

Manusia merupakan sumber daya paling penting dalam usaha organisasi mencapai keberhasilan, sumber daya ini menunjang organisasi dengan karya, bakat, kreativitas dan dorongan. Betapapun sempurnanya aspek teknologi dan ekonomi, tanpa aspek manusia sulit kiranya tujuan dapat dicapai. Masyarakat telah menunjukkan perhatian yang meningkat terhadap aspek manusia tersebut. Nilai-nilai manusia (human value) semakin diselaraskan dengan aspekaspek tehnologi maupun ekonomi.

Adapun sumber daya manusia yang berkualitas menurut Muhammad Sirozi dikutip dari Karel Rogerz menjelaskan sumber daya manusia yang berkualitas adalah yang memiliki kepribadian seimbang, yaitu: 1) Bersikap terbuka, menerima berbagai pengalaman, dan berusaha memahami perasaan-perasaan internalnya, 2) Hidup secara eksistensialistik, yakni memiliki kepuasan batin bahwa tiap saat ia menginginkan pengalaman baru. Ini berarti memiliki perasaan internal bahwa ia bergerak dan tumbuh, 3) Dalam srtuktur keanggotaannya, ia menemukan hal yang dipercaya untuk mencapai tingkah laku yang paling banyak memberikan kepuasan dalam tiap kondisi nyata. Ia melakukan apa yang dirasakannya benar dalam konteks kekinian. Ia berpegang pada pembentukan totalitas dan komprehensif pada dirinya untuk mengarahkan tingkah laku sesuai pengalaman. Jadi dapat kita tarik kesimpulan bahwa peningkatan sumber daya manusia adalah suatu usaha atau proses yang dilakukan dalam mengembangkan potensi yang terdapat dalam diri manusia untuk menbentuk manusia yang beriman dan bertaqwa kepada Tuhan Yang Maha Esa, cerdas, terampil dan profesional;, kreatif, produktif, berakhlak yang luhur, berkepribadian dan disiplin, sadar akan pengabdian dan punya tanggung jawab sosial serta sehat jasmani dan rohani, sehingga siap untuk menghadapi tantangan zaman.

\section{Pengembangan Sumber Daya Manusia}

Pengembangan sumber daya manusia merupakan pilihan yang memiliki arti strategis bagi bangsa Indonesia karena proses pembangunan nasional harus berkesinambungan dan dinamis meniscayakan adanya sumber daya manusia yang berkualitas, disamping itu sumber daya manusia yang berkualitas akan memungkinkan bangsa Indonesia merebut keunggulan kompetitif atas bangsa-bangsa lain didunia. 
Pengembangan sumber daya manusia di masa depan dihadapkan pada era global yang sarat dengan tantangan yang semakin kompleks. Dalam era ini batas-batas politik, ekonomi, dan sosial budaya antar bangsa menjadi begitu transparan sehingga menimbulkan persaingan antar bangsa yang sangat tajam terutama dalam bidang ekonomi serta dalam penguasaan ilmu pengetahuan dan tekhnologi akan dapat mengambil manfaat dari proses ini dapat dicapai terutama dengan peningkatan kualitas SDM yang peka serta mampu memanfaatkan berbagai peluang. Dalam era persaingan global, SDM yang berkualitas adalah mereka yang mampu menguasai suatu bidang keahlian dalam ilmu pengetahuan dan teknologi, mampu melaksanakan pekerjaan secara profesional, serta mampu menghasilkan karya-karya unggul yang dapat bersaing didunia. Penguasaan terhadap berbagai cabang keterampilan dan keahlian yang sesuai dengan perkembangan iptek mutlak diperlukan dalam rangka menggerakkan berbagai sektor industri dalam rangka meningkatkan nilai tambah dan produktivitas nasional secara berkelanjutan. Pembangunan dengan menekankan pada peningkatan SDM inilah yang akan mendorong terciptanya pertumbuhan ekonomi yang berkelanjutan (sustainable economic growth).

Tantangan lain bangsa dimasa depan bersumber dari perubahan yang terjadi dalam berbagai kehidupan, pada dasarnya perubahan merupakan suatu proses yang berkelanjutan baik yang terjadi secara alamiah maupun dampak dari pembangunan yang sistematis. Perubahan yang terjadi secara menyeluruh dan multidimensional sering berakibat terhadap terjadinya transformasi struktural (structural tranformation). Tranformasi struktural inilah yang memberikan dampak sangat mendasar terhadap terjadinya pergeseran nilai, sikap dan perilaku manusia Indonesia yang sekaligus merupakan tantangan bagi usaha pendidikan.

Dalam rangka pengembangan kualitas SDM ini Indonesia diperkirakan akan dihadapkan pada era transformasi masyarakat Indonesia dari agraris menuju masyarakat industri yang ditandai oleh berbagai perubahan fisik, pranata sosial dan adanya pergeseran nilai sistem. Dan sebagai salah satu indikator dari terjadinya proses tinggal landas. Tranformasi tersebut diakibatkan oleh berkembangnya kegiatan ekonomi industrial dengan teknologi yang tepat guna. Perkembangan industri mengakibatkan munculnya jenis-jenis pekerjaan dan kualifikasi jabatan yang beraneka ragam dan memerlukan jenis-jenis keterampilan dan keahlian baru sesuai dengan perkembangan iptek. Jabatan dan keahlian yang semakin beraneka ragam ini juga akan mengakibatkan timbul berbagai bentuk perubahan fisik, pranata sosial, dan pergeseran sistem nilai. Dengan demikian tidaklah mengherankan jika dalam masyarakat kita akan terjadi semacam 
$\int \begin{aligned} & \text { p-ISSN: 2723-4703 } \\ & \text { e-ISSN: - } \\ & \text { http://ejurnal.iaipd-nganjuk.ac.id/index.php/j-kis/ } \\ & \text { KURNAL }\end{aligned}$

benturan antara nilai-nilai tradisional yang melekat pada budaya agraris dengan nilai-nilai budaya industri yang baru berkembang pada sebagian masyarakatnya. Dengan demikian tantangan penting lainnya bagi kita ialah mengembangkan dan menanamkan nilai-nilai budaya industrial yang mampu memacu produktivitas nasional yang tetap berlandaskan nilai-nilai kepribadian bangsa. Dan sasaran utama pengembangan jangka panjang adalah terciptanya kualitas manusia dan kualitas masyarakat Indonesia maju dalam suasana tentram dan sejahtera lahir batin, dalam tata kehidupan masyarakat, bangsa dan negara yang berdasarkan Pancasila, selaras dengan hubungan antara sesama manusia, manusia dengan masyarakat, manusia dengan alam lingkungannya, manusia dengan Tuhan Yang Maha Esa.

Sumber daya manusia adalah kekuatan fisik manusia, pengetahuan, keahlian atau keterampilan, semangat dan kreativitas, kepribadian yang dimiliki oleh individu. Sumber daya manusia yang besar jumlahnya dengan kualitas yang relatif rendah merupakan beban yang cukup berat bagi pembangunan Indonesia, karena penduduk yang besar dengan kondisinya yang masih berat kearah sebagai obyek. Permasalahan utamanya adalah bagaimana menjadikan manusia Indonesia dari posisi obyek dan beban pembangunan menjadi subyek dan asset pembangunan. Dengan demikian untuk penyiapan SDM, maka perlu diperhatikan beberapa hal :

1. Disamping adanya keimanan, sumber daya manusia harus mempunyai visi dan misi untuk kemaslahatan (kesejahteraan dan keselamatan dunia dan akhirat) untuk kemaslahatan.

2. SDM yang mampu menciptakan peluang kerja. Ini erat sekali kaitannya dengan penciptaan lapangan pekerjaan dan kualitas produksinya. Ini semua tidak akan terwujud, jika kualitas dan prestasi SDM nya rendah.

3. SDM mampu mewujudkan keadaan masyarakat dan negara yang damai. Ini mencakup SDM teknis dan SDM non-teknis, sebagaimana uraian diatas. Jadi politisi masuk disini.

4. SDM yang bertanggung jawab untuk kemaslahatan umat dan membawa pada meningkatnya iman dan taqwa.

Hal tersebut diatas harus diterapkan agar mampu menghasilkan kemajuan dunia yang meliputi kemajuan ekonomi, sain, tehnologi dan lain-lain. Dalam kenyataannya, manusia yang mempunyai SDM tinggi terkadang berbuat kerusakan, karena keangkuhannya dan kesombongannya. Untuk jenis manusia seperti ini, Alloh memperingatkan dengan keras. Kerusakan juga mungkin terjadi karena mereka yang mempunyai SDM hebat itu telah mengingkari dan bahkan juga memusuhi Allah. 
Untuk itu Allah memperingatkan bahwa kerusakan di darat dan dilaut bisa terjadi akibat tangan-tangan manusia. Sudah barang tentu, kita akan sadar hanya tangan-tangan SDM yang berkualitas tinggi yang mampu berbuat kerusakan, bukan mereka yang tidak mempunyai kualitas. Kerusakan ini akan terjadi baik secara langsung menjadi sasaran kerja tangan mereka atau menjadi arena eksperimen kualitas keilmuan kerusakan tersebut.

\section{Pentingnya Pengembangan dan Peningkatan Sumber Daya Manusia di Era Globalisasi.}

Pengembangan SDM di masa depan dihadapkan pada era global yang sarat dengan tantangan yang semakin kompleks. Dalam era ini batas-batas politik, ekonomi, dan sosial budaya antar bangsa menjdi begitu transparan sehingga menimbulkan persaingan antar bangsa yang sangat tajam terutama dalam bidang ekonomi serta dalam penguasaan ilmu pengetahuan dan teknologi. Negara yang unggul dalam penguasaan ilmu pengetahuan dan teknologi akan dapat mengambil manfaat besar dari proses ini.keunggulan dalam penguasaan iptek ini dapat dicapai terutama dengan peningkatan kualitas SDM yang peka serta mampu memanfaatkan berbagai peluang.

Dalam menghadapi persaingan global yang semakin ketat ini tidak ada pilihan lain bagi Indonesia kecuali membangun sektor-sektor ekonomi dengan erientasi nilai tambah dalam rangka mencapai tingkat produktivitas nasional tinggi. Orientasi nilai tambah tersebut dapat ditingkatkan melalui peningkatan kualitas SDM, yaitu yang terampil dan menguasai iptek yang dibutuhkan untuk mengembangkan sektor-sektor ekonomi produktif.

Globalisasi yang semakin menggejala ini telah mengakibatkan batas-batas politik, ekonomi, dan sosial-budaya antar bangsa menjadi begitu transparan. Globalisasi menimbulkan persaingan antar bangsa yang semakin tajam terutama dalam bidang ekonomi serta bidang ilmu pengetahuan dan teknologi. Hanya negara yang unggul dalam bidang ekonomi dan penguasaan IPTEK sajalah yang akan dapat mengambil manfaat besar bagi globalisasi. Keunggulan dalam bidang ekonomi dan teknologi dapat dicapai terutama dengan SDM yang berkualitas. Jika kualitas SDM kita lemah, maka banyak peluang yang tidak dapat dimanfaatkan secara maksimal, terlewatkan atau terbuang sia-sia.

Telah menjadi kesadaran yang cukup umum bahwa kemajuan suatu bangsa lebih banyak ditentukan oleh sumber daya manusianya daripada oleh alamnya sesuai dengan pendapat Nur Kholis Madjid dalam bukunya Tradisi Islam. Dan hal ini benar karena suatu negara yang mengandalkan sumber daya alamnya yang banyak dan melimpah seperti Saudi Arabia dia 


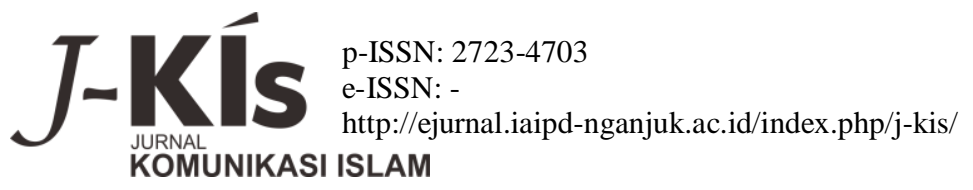

menjadi negara yang kaya, tetapi tidak mampu memainkan peranan dalam pengembangan ilmu pengetahuan dan teknologi. Dan pada akhirnya Saudi Arabia tetap menjadi negara konsumen bagi hasil-hasil teknologi Barat. Dan yang mengandalkan potensi atau pengembangan sumber daya manusia seperti Jepang, Inggris dan lain-lain, mereka cenderung cepat perkembangannya baik itu ekonomi maupun teknologi. Dengan demikian kualitas sumber daya manusia merupakan aset yang paling penting diantara sumber daya-sumber daya yang lain, dalam setiap usaha memajukan suatu masyarakat atau bangsa.

Dalam rangka mempercepat peningkatan sumber daya manusia yang berkualitas ada beberapa hal yang harus diperhatikan, antara lain sebagai berikut: 1) Pendidikan, yang dapat memberikan kemampuan-kemampuan intelektualitas yang terlibat dalam proses kreatif, 2) Teknologi, yang memberikan kemudahan-kemudahan teknis dan standard kerja yang produktif, 3) kemajuan ekonomi, yang memberikan dampak psikologis untuk menampilkan diri lebih baik dan kebutuhan untuk memperbaiki kesejahteraan masyarakat, 4) Terbukanya mobilitas vertical didalam masyarakat, yang dapat merangsang orang untuk mencapai posisi yang lebih tinggi melalui prestasi-prestasinya. Dengan adanya keempat hal diatas akan terwujudlah cita-cita bangsa yang mempunyai kualitas sumber daya yang berkualitas. Yang mampu berkompetisi dengan negara-negara lain dan dapat mengembangkan potensi-potensi yang diimbangi dengan kualitas dan produktivitas yang tinggi.

Dan yang bertanggung jawab menggarap masalah ini, dipikulkan pada: Pertama: Lembaga keluarga, yang dapat memberikan teladan, etika, disiplin, tata cara berkomunikasi, nilai-nilai agama, kesopanan dan lain-lain. Kedua: Lembaga Pendidikan dan Latihan, yang memberikan pengetahuan, metodologi, motivasi formal, teori-teori dan lain-lain. Ketiga: Lembaga sosial (baik organisasi kemasyarakatan, perusahaan maupun lembaga keagamaan), yang dapat menambah hal-hal yang diberikan oleh kedua lembaga terdahulu, disamping memberikan dorongan atau motivasi dan kesempatan untuk berprestasi. Keempat: Lembaga Pemerintah, untukmemberikan legalitas dan peraturan perundangan yang mendukung terselenggaranya segala upaya pengembangan dan peningkatan sumber daya manusia tersebut, disamping dukungan-dukungan lain. Dengan menggunakan lembaga-lembaga tersebut diatas akan lebih mudah kita dalam meningkatkan SDM yang berkualitas tinggi dan melahirkan potensi manusia yang kreatif, produktif dan berkepribadian. 
Peningkatan kualitas sumber daya manusia membutuhkan penguasaan ilmu dan teknologi demikian rupa melalui sistem pendidikan yang memungkinkan untuk pencapaian penguasaan ilmu pegetahuan dan teknologi. Sementara itu kita menghadapi perkembangan mutakhir epistimologi ilmu pengetahuan dan fungsi teknologi yang terikat pada nilai dan fungsinya untuk kepentingan kesejahteraan umat manusia atau bangsa pada khususnya. Dengan perkataan lain, disatu sisi kita menghadapi persaingan untuk menguasai ilmu dan teknologi sehingga sejajar, kalau tidak lebih tinggi dari bangsa lain di dunia, sekaligus kita, disisi lain, menghadapi gelombang yang dahsyat akan keraguan para ilmuwan terhadap konsep, prinsip, metodologi dan fungsi iptek dilihat dari pendekatan integralistik, dan mungkin juga holistik seperti halnya kita menghadapi perubahan dan perkembangan budaya pada pasca modernisme.

Kemajuan teknologi dalam era globalisasi itu mengakibatkan interaksi budaya akan berjalan dengan semakin intensif dan terbuka, sehingga berdampak pada terjadinya perubahan budaya yang amat fundamental. Itulah globalisasi budaya yang menyebabkan terjadinya perubahan pola dan gaya hidup, bahkan nilai-nilai dan tatanan kehidupan manusia di dunia, tak terkecuali di Indonesia. Oleh karena itu, perlu kita sadari bahwa globalisasi tidak selalu membawa dampak positif bagi umat manusia, bahkan tampaknya akan menjadi semacam "ideologi baru" yang siap menerkam nilai-nilai dan tatanan kehidupan kita bermasyarakat, berbangsa dan bernegara.

Dalam globalisasi budaya ini, paling tidak ada tiga hal kehidupan kita yang berubah dan cenderung terus berubah, yaitu budaya 3-F: budaya makan (food), budaya berbusana (fashion), dan budaya untuk memenuhi kesenangan hidup (fun). Ini bukan suatu yang enteng dan juga tidak main-main, karena akibatnya akan cukup besar terhadap tatanan kehidupan sosial ekonomi bangsa kita. Ambil saja contoh dalam hal makanan. Budaya makan kita sudah mulai terjajah oleh budaya makan dari luar. Buah kiwi lebih dikenal daripada buah sawo, dan salad lebih dikenal daripada gado-gado. Apabila pola makan asing menjadi budaya makan masyarakat kita, maka demand terhadap makanan asing akan meningkat. Dikarenakan produk makanan asing itu tidak dapat sepenuhnya dihasilkan didalam negeri, maka impor akan meningkat. Pada gilirannya, struktur produksi nasional kita akan tergantung kepada komponen luar, sehingga tidak mendorong produksi dalam negeri. Devisa juga akan bocor dan mengalir keluar. Akibatnya lebih jauh adalah pendapatan nasional berkurang sehingga pembangunan akan terancam kemandegan. Bayangkan, betapa berat konsekuensi yang harus kita tanggung apabila 3-F (food, fashion, dan fun) bangsa kita dijajah oleh budaya asing. Moral dan jati diri kita sebagai bangsa Indonesia akan 
$\int \begin{aligned} & \text { p-ISSN: } 2723-4703 \\ & \text { e-ISSN: - } \\ & \text { http://ejurnal.iaipd-nganjuk.ac.id/index.php/j-kis/ } \\ & \text { KURNALUNIKASI ISLAM }\end{aligned}$

terancam. Dan kita harus pandai memilih dan memilah. Dengan demikian kita harus memperkukuh moral dan budaya bangsa tanpa mengabaikan peningkatan daya saing, meningkatkan penguasaan ilmu pengetahuan dan teknologi dalam rangka mengembangkan kualitas sumber daya manusia.

Telah menjadi kesadaran yang cukup umum bahwa kemajuan suatu bangsa lebih banyak ditentukan oleh sumber daya manusianya daripada oleh alamnya. Tetapi sumber daya manusia disini tidak hanya kita pandang sebagai "faktor produksi" setara dengan sumber daya lain, karena manusia adalah makhluk Tuhan yang paling sempurna wujudnya. Hal ini jelas karena akal kreatif manusia (potensi akal) dan rasa ekspresinya (potensi qalbu) menjadikannya mampu mempertahankan eksistensinya sebagai pembawa amanah "ibadah" dan sekaligus "khalifah" ditengah-tengah posisinya yang unik dalam sistem kemakhlukan dan posisinya yang menonjol dalam hubungan dengan Tuhan. Manusia yang mampu mengembangkan sumber dayanya seperti itu yang mendapat konsesi luas dari Tuhan untuk menundukkan dan mendaya gunakan sumber daya-sumber daya lain, baik sumber daya alam, maupun sumber daya teknologi, bahkan mungkin sumber daya supranatural yang tidak teridentifikasi.

Untuk meningkatkan kualitas manusia dan sumber dayanya yang perlu diperhatikan pada umumnya ada 4 (empat) dimensi, yakni:

\section{Dimensi Kepribadian}

Yaitu merupakan hasil suatu proses sepanjang hidup yang dilalui seseorang yang berbeda dalam menentukan tingkah laku yang sempurna baik jasmani maupun rohani. Pembentukan kepribadian itu ditentukan oleh pengetahuan seseorang ( sikap, jujur, sopan, tindakan sehari-hari) msehingga individu dapat menyesuaikan diri dengan lingkungannya.

Malayu menulis bahwa kepribadian adalah serangkaian ciri yang relatif tetap dan sebagian besar dibentuk oleh faktor keturunan, sosial, kebudayaan, dan lingkungan. Dibawah sketsa tentang kekuatan-kekuatan yang mempengaruhi kepribadian:

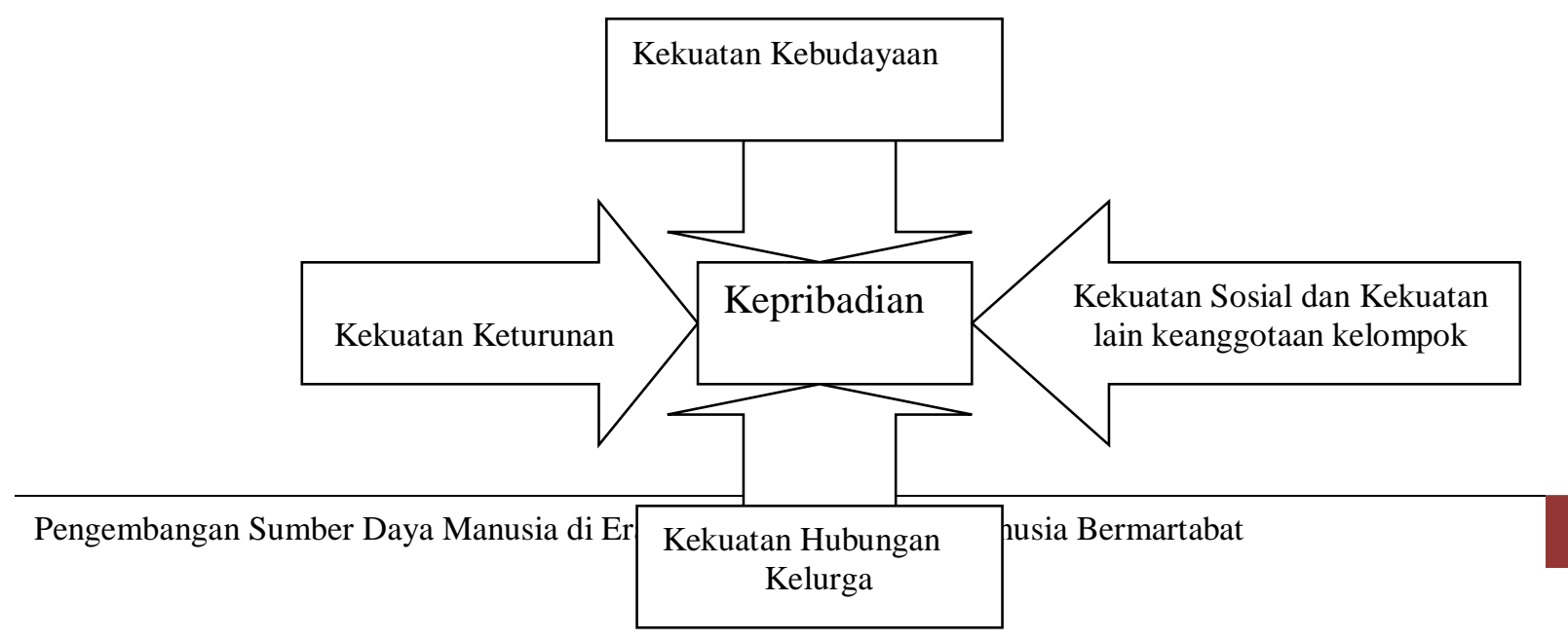


Gambar 2.1

Kekuatan-kekuatan yang mempengaruhi kepribadian

Kekuatan-kekuatan utama yang mempengaruhi kepribadian seseorang adalah kekuatan keturunan, kekuatan budaya, kekuatan hubungan keluarga dan kelas sosial atau pendidikan, dan kekuatan lain dari keanggotaan kelompok. Kekuatan-kekuatan utama yang mempengaruhi kepribadian digambarkan pada konsep Gambar 2.1.

Pertumbuhan dan perkembangan hidup umat manusia dari generasi ke generasi tidak terlepas dari proses pembentukan dan pembinaan kepribadian, yang kemudian saling memberikan pengaruhnya dalam kehidupan bersama.

Dalam pembentukan kepribadian banyak faktor yang ikut mempengaruhinya, antara lain adalah lingkungan, seperti penyesuaian terhadap lingkungan. Proses pembentukan yang dialami seseorang itu berbeda-beda, maka kepribadian tiap-tiap individupun berbeda-berbeda, antara individu yang satu dengan yang lain, sehingga bersifat unik. Tidak ada kepribadian yang sama antara seseorang dengan orang lainnya di dunia ini yang sama, meskipun saudara kembar dari satu rahim ibu, karena manusia hidup didunia ini dapat sistematis dan berencana tergantung pada diri seseorang dengan lingkungannya dan seseorang itu dapat mengupayakan terbentuknya satu sikap kepribadian yang diharapkan.

Ada beberapa proses pembentukan kepribadian, yaitu kepribadian terbentuk setelah mengikuti proses sebagai berikut:

a. Adanya nilai yang diserap seseorang dari berbagai sumber, mungkin agama, ideologi, pendidikan, temuan sendiri, atau lainnya.

b. Nilai membentuk pola pikir seseorang yang secara keseluruhan keluar dalam bentuk rumusan visinya.

c. Visi turun ke wilayah hati dan membentuk suasana jiwanya yang secara keseluruhan keluar dalam bentuk mentalitas.

d. Mentalitas mengalir memasuki wilayah fisik dan melahirkan tindakan yang secara keseluruhan disebut sikap.

e. Sikap-sikap yang dominan dalam diri seseorang yang secara akumulatif mencitrai dirinya adalah apa yang kita sebut sebagai kepribadiannya. 


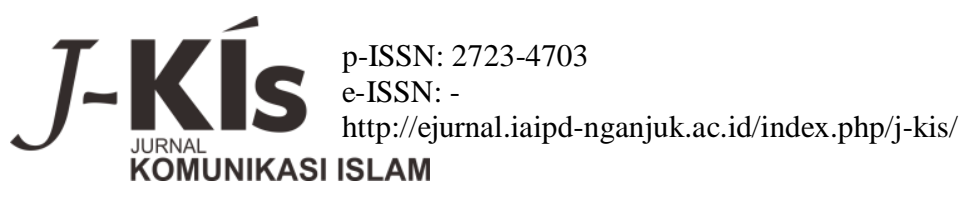

Dengan proses diatas kepribadian jelas terbuka untuk dikembangkan, dan ia bukanlah sesuatu yang tiba-tiba jadi dan baku, tetapi dapat dapat dirubah dan dikembangkan untuk menunjang peningkatan kualitas manusia. Kepribadian merupakan dimensi sentral dalam upaya pengembangan sumber daya manusia, menginggat eksistensinya sebagai pelaku pembangunan dan makna pembangunan. Pada akhir-akhir ini, masalah kepribadian ini semakin memperoleh perhatian, karena hasil dari berbagai penelitian menunjukkan, bahwa keinggian IQ tidak banyak menentukan kesuksesan hidup seseorang. Daniel Goleman yang dikutip oleh Moh. Tholhah Hasan, menunjukkan data-data bahwa mereka yang sukses dalam karier, yang mencapai puncak prestasinya , justru mereka yang mempunyai kecerdasan emosional, mampu mengendalikan diri, tabah menghadapi tantangan. Teori Goleman diperkuat algi dengan teori Adversity Quotien (AQ) yang ditulis Paul G. Stoltz, yang menyatakan, bahwa kemampuan mengatasi kesulitan sangat berperan dalam keberhasilan seseorang. dia "mampu mengubah tantangan menjadi peluang".

Spiritualitas yang bersumber pada keimanan dan kesadaran religius, akan memberikan kontribusi yang besar terhadap pengembangan kepribadian dalam rangka peningkatan kualitas sumber daya manusia. Kepribadian yang berkualitas mempunyai ciri-ciri antara lain: Religius dan ethis, mandiri dalam kebersamaan, bertanggung jawab, rasional, tenggang rasa, bersikap terbuka, berwawasan luas, mempunyai kepekaan sosial, jujur dan satria, sederhana tapi tertib/disiplin, penuh pengabdian dan semangat berprestasi.

\section{Dimensi Kretivitas}

Dimensi kreativitas adalah kemampuan seseorang untuk berpikir yang kreatif, pandai memanfaatkan kesempatan, inovatif, trampil, banyak mempunyai alternatif-alternatif.

Dalam proses peningaktan sumber daya manusia, terutama yang penting diperhatikan adalah ciri-ciri individu yang kreatif, yang antara lain dikemukakan oleh Robert B. Sund, sebagai berikut: a) Berhasrat ingin mengetahui, b) Bersikap terbuka terhadap pengalaman baru, c) panjang akal dan penalaran, d) keinginan untuk menemukan dan meneliti, e) Cenderung lebih suka melakukan tugas yang berat dan sulit, f) Mencari jawaban yang memuaskan dan komprehensip, g) Bergairah, aktif dan berdedikasi tinggi dalam melakukan tugasnya, h) Berfikir fleksibel dan mempunyai banyak alternative, i) Menanggapi pertanyaan dan kebiasaan serta memberikan jawaban lebih banyak, j) Mempunyai kemampuan membuat analisis dan sintesis, k) Memmpunyai kemampuan membentuk abatrak-abstraksi, 1) Memiliki semangat inquiry 
(mengamati/menyelidiki masalah), m) memiliki keluasan dalam kemampuan membaca. Dengan ciri-ciri diatas setiap individu harus mampu menciptakan kualitasnya melalui kreativitas yang ada pada diri individu tersebut, dengan harapan dapat berguna bagi masyarakat luas. Dan berperan penting dalam pengembangan sumber daya manusia yang berkualitas.

Manusia dalam pandangan Islam adalah "makhluk unggulan” yang dikaruniai akal kreatif sehingga memungkinkannya untuk mengembangkan peradapan dan kebudayaannya. Dalam hal ini akal kreatif manusia (potensi akal) dan rasa ekspresinya (potensi qalbu) menjadikan dia mampu mempertahankan eksistensinya sebagai pembawa amanah ibadah dan sekaligus khalifah ditengah-tengah posisinya yang unik dalam sistem kemakhlukan dan posisinya yang menonjol dalam hubungannya dengan Tuhan.

Dengan demikian kreativitas manusia hendaknya harus mampu menciptakan iklim swadaya, yang memberikan setiap manusia peluang dan kebebasan untuk secara mandiri meningkatkan dan mengembangkan kualitas dirinya.

3. Dimensi Produktivitas

Dimensi produktifitas adalah cukup pengetahuan, menguasai sistem dan peralatan, mempunyai gairah untuk berprestasi, profesional, disiplin dan mempunyai etos kerja dan juga menghargai waktu.

Dalam masyarakat yang terus berubah dan berkembang sistem pendidikan memiliki peranan yang sangat mendasar dalam menanamkan berbagai nilai-nilai produktivitas individu masyarakat. Berikut ini saya kemukakan beberapa nilai manusia Indonesia yang produktif, yaitu (1) Iman dan Taqwa; (2) Kemandirian; (3) Keunggulan; (4) Keahlian dan Profesionalisme; (5) Kebersamaan dan Kekeluargaan. Nilai-nilai tersebut saya jelaskan sebagai berikut:

Pertama, Iman dan Taqwa; dalam GBHN 1993 ditegaskan bahwa kehidupan beragama dikembangkan sehingga terbina kualitas keimanan dan ketaqwaan terhadap Tuhan Yang Maha Esa, kualitas kerukunan antara umat beragama, serta memperkukuh kesatuan dan persatuan bangsa, meningkatkan amal dan bersama-sama membangun masyarakat. Pembangunan nasional yang telah berhasil dicapai sampai saat ini merupakan manifestasi dari kemampuan perilaku bangsa Indonesia yang tercipta atas dasar nilai iman dan taqwa. Nilai-nilai keimanan dan ketaqwaan ini perlu terus dikembangkan sehingga mampu mendukung semangat untuk berkarya dan sebagai salah satu aspek dari unsur keimanan.

Kedua, Kemandirian; kemandirian bangsa Indonesia dalam era tinggal landas ialah kesiapan bangsa Indonesia menghadapi tantangan masa depan. Kesiapan dalam menghadapi 
$\int \begin{aligned} & \text { p-ISSN: } 2723-4703 \\ & \text { e-ISSN: - } \\ & \text { http://ejurnal.iaipd-nganjuk.ac.id/index.php/j-kis/ } \\ & \text { KURNAL }\end{aligned}$

persaingan global, peningkatan nilai tambah, dan transformasi menuju masyarakat industri dapat dibangun melalui penguasaan berbagai keahlian dan keterampilan dalam ilmu pengetahuan dan teknologi. Kemandirian itu sendiri ialah suatu sikap yang dibentuk oleh kemampuan individu atau suatu bangsa untuk mengaktualisasikan seluruh potensinya sehingga dapat menghasilkan buah karyanya sendiri untuk pembangunan. Untuk mewujudkan kemandirian bangsa, perlu ditanamkan sikap dan nilai kemandirian pada tingkatan individu. Sikap kemandirian itu sendiri bersumber dari kemampuan individu dalam menguasai keterampilan keahlian yang diperlukan tidak tergantung kepada kekuatan atau kemampuan orang lain. Sikap ini dapat dikembangkan pada setiap jenis dan jenjang pendidikan dengan membentuk sumber daya manusia Indonesia yang mampu belajar terus menerus dan selalu menyesuaikan diri dengan perubahan zaman.

Ketiga, Keunggulan; didalam mengahadapi era persaingan, bangsa Indonesia dituntut untuk mampu menghasilakan karya yang bermutu tinggi dan mampu bersaing dengan karyakarya bangsa lain didunia. Kemampuan bangsa Indonesia untuk mengahasilkan keunggulan dibentuk dari kekuatan setiap individu dalam menguasai keterampilan dan keahlian.

Keempat, keahlian dan profesionalisme; penguasaan keahlian dan profesionalisme sangat diperlukan untuk mendukung pembentukan sikap kemandirian dan keunggulan seperti disebutkan diatas. Untuk menguasai keahlian perlu ditanamkan motivasi untuk mengeksplorasi lingkungan dan sumber-sumber kekuatan alam, yang akan menjadikan manusia tidak tunduk terhadap nasib tetapi menganggap penting usaha dan kemampuannya sendiri untuk selalu melakukan inovasi, perubahan, dan penyempurnaan dalam berbagai bidang kehidupan. Untuk itu maka kemampuan bangsa Indonesia menguasai ilmu pengetahuan dan teknologi perlu terus ditingkatkan agar mampu membudidayakan sumber-sumber alam untuk kesejahteraan umat manusia.

Kelima, Kekeluargaan; masyarakat Indonesia dikenal sebagai negara yang berdasarkan asas kekeluargaan. Dengan demikian upaya peningkatan mutu pendidikan harus merupakan usaha bersama di dalam suatu kerja sama khususnya antar kelompok yang seprofesi. Melalui kerjasama ini maka tukar menukar pengalaman akan terjadi secara berkelanjutan sebagai salah satu wahana penting dalam memacu semangat belajar.

Nilai-nilai tersebut diatas harus menjadi acuan dalam rangka meningkatkan produktivitas individu, untuk mewujudkan sumber daya manusia yang berkualitas dalam menghadapi era globalisasi. 
Produktifitas manusia adalah manusia yang mampu bekerja atau berkarya, dan merasa mengenal serta menguasai metode-metode kerja yang terdapat dalam berbagai bidang garapannya. Tanpa perasaan-perasaan ini, tanpa kepercayaan-kepercayaan ini, orang tidak mampu produktif. Namun demikian suatu hal yang tidak boleh dilupakan, bahwa produktivitas adalah fungsi kerja, dan bahwa sifat produktif adalah mafestasi dari dorongan bekerja yang ada dalam diri seseorang.

Dengan demikian manusia produktif adalah manusia yang memiliki ciri-ciri dasar: percaya kepada dirinya sendiri (sebagai akibat dari kesediaan serta kemampuannya untuk untuk menerima seluruh keadaan dirinya secara ikhlas); mencintai lingkungannya; memahami persoalan dan kebutuhan zamannya, dan dapat bekerja berdasarkan metode tertentu.

\section{Dimensi Spiritualitas}

Dimensi spiritualitas adalah ketaqwaan sebagai prestasi rohani, yang bersumber pada keimanan sebagai potensi rohani yang teraktualisasi dalam amal-amal saleh; baik dalam ibadah, moral, kepedulian sosial, sehingga terwujud sebagai kesalehan hidup (individu maupun sosial).

Spiritual manusia yang bersumber pada keimanan dan ketaqwaan, memberikan beberapa macam kesadaran eksistensinya yaitu: kesadaran akan hidupnya yang terbatas, kesadaran akan keprihatinan hidup sebagai penugasan, kesadaran akan pencarian makna hidup, kesadaran akan pendayagunaan nikmat dan mensyukurinya dan kesadaran akan kemungkinan terjadinya kelalaian karena terkecoh godaan hidup.

Berbagai agama telah menyajikan pedoman serta patokan untuk mengadakan sintesa atau keterpeduan masing-masing terhadap eksistensial manusia, tetapi ramuan khas yang ditawarkan oleh agama merupakan ramuan kerohanian, suatu pemecahan yang bercorak spiritual.

Selain itu sebagai manusia beragama, diperlukan tumbuhnya kepribadian yang religius dan berakhlakul karimah, sehingga kualitas diri yang dimiliki tersebut diimbangi dengan ketahanan mental dan kemakmuran spiritual yang handal.

Keempat dimensi tersebut merupakan faktor-faktor penunjang dalam pengembangan kualitas sumber daya manusia di era globalisasi yang harus terwujud di Indonesia, karena dalam era persaingan global, SDM yang berkualitas adalah mereka yang mampu menguasai suatu bidang keahlian dalam ilmu pengetahuan dan teknologi, mampu melaksanakan pekerjaan secara profesional, serta mampu menghasilkan karya-karya yang unggul yang dapat bersaing didunia. Penguasaan terhadap cabang keterampilan dan keahlian yang sesuai dengan perkembangan ilmu pengetahuan dan teknologi Sebagai nilai tambah kualitas SDM dalam perspektif Islam, bukan 
$\int \begin{aligned} & \text { p-ISSN: } 2723-4703 \\ & \text { e-ISSN: }- \\ & \text { http://ejurnal.iaipd-nganjuk.ac.id/index.php/j-kis/ } \\ & \text { KURNAL }\end{aligned}$

saja untuk mengejar kehebatan sains dan skill untuk meningkatkan produktifitas, namun harus pula meliputi iman sekaligus menjauhi kemungkaran.

Manusia dibekali oleh Tuhan dengan beberapa potensi dasar yang sangat membantu dalam rangka mengembangkan kualitas sumber daya manusia. Potensi-potensi dasar tersebut adalah sebagai berikut:

a. Potensi Jasmani (fisik)

Potensi jasmani yaitu kekuatan dan ketahanan seseorang untuk melakukan pekerjaan yang berat dan bekerjanya lama, maupun ketahanannya menghadapi serangan penyakit. Misalnya, ada orang yang hanya mampu bekerja 4 jam sehari, tetapi ada yang sampai 8-10 jam sehari.

Potensi jasmani menurut ilmu kesehatan memerlukan gizi dan berbagai vitamin termasuk udara yang bersih dan lingkungan yang sehat sebagai prakondisi hidupnya. Jika kebutuhan jasmaniah ini sebagian tidak tercukupi, maka tubuh orang yang bersangkutan akan lemah, bahkan dapat sakit. Karena itulah ilmu kesehatan dan ilmu ekonomi berusaha meningkatkan kesejahteraan jasmani manusia.

Dalam hal ini potensi jasmani (fisik) sangat penting dan sebagai penentu untuk mencapai cita-citanya. Fisik yang lemah karena penyakit, atau kurangnya gizi, akan megurangi kemampuan seseorang.

Walaupun pada kenyataannya manusia bukan semata-mata fisik. Banyak orang yang memiliki cacat fisik, tetapi memegang peranan besar dalam sejarah peradaban manusia yaitu, Sookrates (469-399), Failasuf Yunani klasik, Immanuel Kant (1724-1804) Failasuf Jerman, Thaha Husain, sarjana Mesir, dan banyak lagi yang lain adalah manusia-manusia yang berkualitas yang tidak mempunyai kesempurnaan fisik. Akan tetapi faktor kesehatan fisik walau bagaimanapun sangat menentukan dalam pencapaian cita-cita ataupun dalam menjalani kehidupan kita sehari-hari.

Dalam upaya meningkatkan potensi fisik ada beberapa hal yang harus diperhatikan yaitu:

1) Makan makanan yang bergizi tinggi.

2) Pemeliharaan kesehatan yang baik.

3) Olah raga yang baik dan teratur.

4) Mengikuti pertandingan-pertandingan.

5) Dan lain sebagainya. 
Dengan memperhatikan hal tersebut potensi jasmani manusia semakin meningkat dan sangat ,menunjang proses pengembanganm diri untuk meningkatkan sumber daya manusia yang berkualitas. Dengan adanya potensi jasmani, manusia memiliki kelebihan dari makhluk-makhluk lain . manusia dapat menggunakan anggota tubuhnya secara lebih bebas dari makhluk-makhluk lain. Dengan demikian, ia dapat beraktivitas dalam mengembangkan keterampilan kerja, yang dijadikannya modal bagi pengembangan teknologi.

b. Potensi Nalar (akal/ratio)

Potensi nalar yakni daya untuk berpikir (kecerdasan yang dibawa sejak lahir sebagai modal dasar). Sedangkan kecakapan diperoleh dari usaha (belajar dan pelatihan). Kecerdasan tolak ukurnya adalah Intelegence Quotient (IQ). EQ adalah kemampuan manusia untuk mengendalikan emosi dan bersosialisasi (bermasyarakat). Apabila IQ didukung oleh EQ maka realisasi pendapat-pendapatnya akan disambut baik dan antusias oleh masyarakat. Dan juga Dengan daya akal manusia dapat mengembangkan ilmu pengetahuan, suatu daya yang tidak dimiliki oleh makhluk lain. Dalam upaya meningkatkan potensi nalar/pikir ada beberapa hal yang harus diperhatikan yaitu sebagai berikut:

1) Makan makanan yang bergizi tinggi.

2) Pemeliharaan kesehatan yang baik.

3) Pendidikan formal dan informal.

4) Mengikuti diskusi dan seminar-seminar.

5) Dan lain sebagainya.

Dengan menggunakan beberapa upaya diatas perilaku seseorang akan dapat ditingkatkan dalam runah tangga yang sakinah, lingkungan pergaulan yang baik, pembinaan iman yang baik, pelaksanaan hukum yang adil dan tegas, menjadi contoh tauladan yang menjadi panutan penghayatan budaya dan sebagainya.

Dan kita diberi Allah akal untuk berpikir. Ada naluri akal yaitu "ingin tahu" yang harus kita tunjang dengan kemampuan bertanya, memiliki kreativitas, serta inovasi dalam mengembangkan pertanyaan. Akal juga memiliki hanya dua nilainya; betul dan salah. Dengan mengembangkan pertanyaan kita akan mendapatkan berbagai pengetahuan, teknologi, kemampuan mengatur, serta hukum baik dari Allah maupun yang disusun oleh manusia. Dalam hal ini jelas bahwasanya hidup manusia tak terlepas dari upaya proses untuk merebut pengetahuan. Upaya demikian sejalan dengan watak manusia itu sendiri yang senantiasa ingin tahu. 


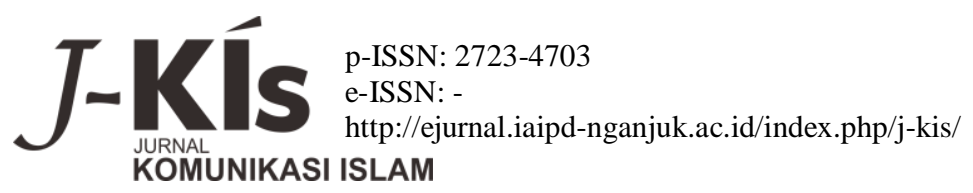

Bagi Islam, akal merupakan salah satu sarana untuk mendapat ilmu, dan ilmu yang diperoleh melalui penalaran akal disebut sebagai pengetahuan ilmiah atau ilmu pengetahuan. Akal dan pikiran juga sebagai alat utama bagi SDM untuk pemguasaan dan pengembangan ilmu dan teknologi. Menurut Islam, ilmu merupakan pelayan kebenaran. Jadi, tujuan mendapatkan ilmu adalah untuk mendapatkan kebenaran. Ilmu hanyalah perantara untuk sampai kepada kebenaran. Oleh sebab itu, ilmu memiliki kesucian, karena digunakan untuk mendapatkan kebenaran dari Tuhan Yang Maha Benar. Ilmu memiliki elemen keilahian, karena ilmu itu sendiri adalah salah satu sifat Ilahi. Betapa ketinggian ilmu tercermin pada kisah penciptaan Adam a.s dimana para malaikat tunduk kepadanya, karena ilmu yang di milikinya, ini sesuai dengan kisah di Al-Qur'an.

c. Potensi Hati Nurani (Qalbu)

Potensi ruhani yaitu kesadaran ketuhanan dan keagamaan, yakni kesadaran moral yang meningkatkan harkat dan martabat manusia menjadi manusia yang berbudi luhur, atau insan kamil; ataupun manusia yang taqwa menurut agama masing-masing. Penggunaan potensi nurani (hati) secara optimal akan dapat mengantarkan manusia untuk menguasai dirinya sendiri dan segala produk yang dihasilkannya. Manusia yang menggunakan daya nalar dan hatinya secara optimal dan berimbang tanpa melanggar ketentuan-ketentuan ilahi itulah, agaknya yang disebut manusia pari purna (insan kamil). Tegasnya bangsa menghendaki agar manusia memiliki ilmu dan moral yang dilandasi oleh ketaqwaan dan iman serta mampu berbuat baik dalam hidupnya.

Pemberdayaan hati (naluri) ialah melalui pendidikan akhlak, yang mengacu kepada peningkatan penghayatan hati agar lebih peka terhadap nilai-nilai moral keagamaan. Upaya peningkatan penghayatan hati agaknya harus dimulai dengan pembinaan pengalaman ajaran agama secara kontinu, kemudian ditingkatkan dengan penyucian hati (tazkiyah al-nafs) dan pengenalan diri (ma'rifah al-nafs), yang akhirnya akan mengantarkan manusia untuk sampai dapat merasakan kehadiran Tuhan didalam hidupnya. Tegasnya, sejak dini setiap anak harus sudah dididik dengan akhlak mulia melalui pembiasaan, sehingga akan memberi efek kepada pembentukan kepribadiannya. Sebab, kebiasaan akan membentuk tabiat; tabiat akan melahirkan kepribadian. Orang yang sudah terbiasa melakukan yang baik, maka tabiatnya akan baik, dan tabiat baik akan mengantarkannya menjadi satu pribadi yang baik pula. Proses selanjutnya ialah menyadarkan diri akan perilaku luhur, yang sejak sebelumnya telah dibiasakan itu. Untuk itu, ia harus senantiasa meningkatkan kesadaran hati dan pikiran kepada Alloh. 
Keutuhan pengembangan ketiga potensi dasar manusia tersebut akan memberikan kualitas manusia yang utuh pula. Disitulah pentingnya peranan agama, moral, kesehatan dan lingkungan hidup, disamping ilmu pengetahuan dan teknologi. Tapi sebaliknya, apabila pengembangan potensi dasar manusia tersebut tidak dilakukan secara berimbang dan harmoni, dampaknya mewujudkan hadirnya manusia-manusia pecah kepribadian dan krisis dimensi, kuat tapi bodoh, atau cerdas tapi jahat, atau etis tapi lemah. Dengan demikian, kualitas SDM pada intinya terletak pada kualitas ilmu dan akhlak, yang ditopang dengan kualitas ketrampilan yang memadai. Secara karikatural SDM yang andal itu digambarkan sebagai manusia yang berkepala botak, yang hidup di tengah-tengah hiruk-pikuk teknologi modern, tetapi tidak lupa memegang tasbih dan berkomunikasi dengan masyarakat sekitarnya. Untuk dapat mencapai kualitas sumber daya manusia yang berkualitas dan dapat berkembang secara maksimal harus ada pembinaan baik melalui pendidikan baik itu pendidikan formal, informal, non formal.

\section{Sumber Daya Manusia di era Globalisasi yang Bermartabat}

Era globalisasi merupakan tantangan sekaligus persaingan dan peluang. Semua bangsa dan semua golongan pasti akan terlibat dan harus mau melibatkan diri dalam era ini, walaupun dengan kualitas yang berbeda. Dalam mempersiapkan diri memasuki era ini, yang pada hakekatnya sudah berjalan, khusus bagi umat Islam, ialah dengan merujuk al-Qur'an sebagai referensi utama dan pertama umat Islam.

Al-Qur'an diturunkan sebagai petunjuk bagi manusia sekaligus pembawa rahmat, untuk mengangkat harkat dan martabatnya, hal ini sesuai dalam firman Allah SWT Q.S. Ibrahim: 1 yang berbunyi:

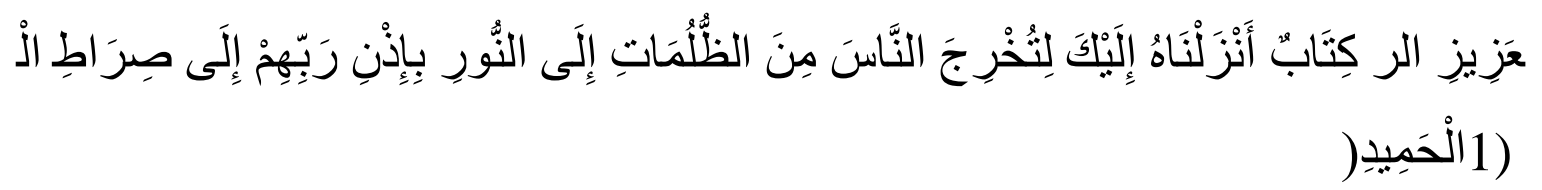

Alif, laam raa. (ini adalah) kitab yang Kami turunkan kepadamu supaya kamu mengeluarkan manusia dari gelap-gulita kepada cahaya terang-benderang dengan izin Tuhan mereka, (yaitu) menuju jalan Tuhan Yang Maha Perkasa lagi Maha Terpuji.

Dengan kapasitasnya itu al-Qur'an memerankan dirinya sebagai pembangunan manusia dan kemanusiaan dalam segala aspek kehidupan. Membangun manusia dan kemanusiaan adalah titik sentral peranan al-Qur'an, sehingga manusia mampu menyelesaikan permasalahan hidupnya dengan baik. Jenis dan kualitas pembangunan yang disebut belakangan ini terasa amat perlu 
$\int \begin{aligned} & \text { p-ISSN: } 2723-4703 \\ & \text { e-ISSN: - } \\ & \text { http://ejurnal.iaipd-nganjuk.ac.id/index.php/j-kis/ } \\ & \text { KURNALUNIKASI ISLAM }\end{aligned}$

sebab manusia "ditunjuk" sebagai khalifah di muka bumi untuk membangun dunia yang indah, sejahtera, damai dan adil sesuai dengan pentunjuk-Nya.

Pengembangan kualitas manusia itu bisa dengan memperkokoh pemahaman dan keimanan agama Islam, bisa juga dengan meningkatkan ilmu pengetahuan dan teknologi yang dimiliki. Penguasaan iptek oleh umat Islam (salah satu aspek yang sangat menentukan kebesaran dan kemajuan suatu bangsa atau umat), dimaksudkan agar umat Islam bisa berperan di tengahtengah kemajuan peradaban itu.

Manusia pada hakikatnya adalah makhluk Allah yang paling sempurna di antara makhluk lainnya. Manusia mempunyai beberapa kelebihan, diantaranya: 1) mampu bergerak dalam berbagai ruang, baik di darat, di laut, maupun di udara, 2) mempunyai potensi untuk berbuat baik (akal) dan berbuat yang tidak baik (nafsu). 3) memegang amanah sebagai khalifah Allah. Kelebihan-kelebihan manusia dari makhluk lainnya disebutkan oleh Allah dalam Al-Qur'an Surat At-Tin ayat 4 yang berbunyi:

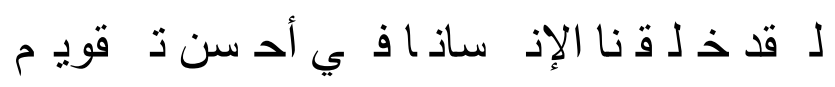

"Sesungguhnya Kami menciptakan manusia dalam keadaan yang sebaik-baiknya".

Dalam ayat tersebut, dapat diketahui dan dipahami bahwa manusia lebih sempurna bila dibandingkn dengan makhluk lainnya. Hal ini, berarti manusia mempunyai proses penciptaan dan karakter yang berbeda dengan makhluk lain.

Islam atau tegasnya Al-Qur'an membicarakan manusia dari Adam, sebagai bapak manusia, yang diciptakan oleh Allah, dari tanah seperti terkandung dalam surat Al-An'am:2:

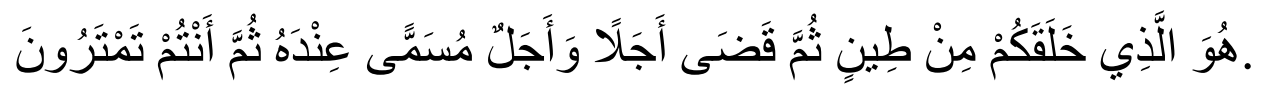

"Dialah yang menciptakan kamu dari tanah, sesudah itu ditentukannya ajal (kematianmu).

Dan selanjutnya manusia diciptakan Tuhan dari ekstrak tanah (sulalah) yang berupa air mani (nuthfah) setelah masuk dalam rahim mengalami sebuah proses kreatif secara bertahap dan muncul sebagai manusia yang disamping memiliki wujud ragawi juga menerima "ruh" dari Allah, sebagai sifat ekselensi manusia ditengah-tengah makhluk lain, seperti yang terkandung dalam surat Al-Hijr ayat 29:

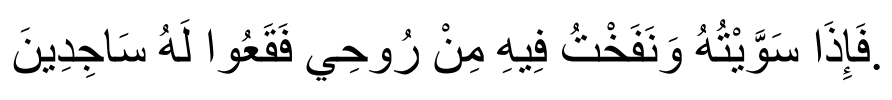


Maka apabila Aku telah menyempurnakan kejadiannya, dan meniupkan ke dalamnya ruh (ciptaan)-Ku, maka tunduklah kamu kepadanya dengan bersujud (sebagai penghormatan bukan menyembah).

Sejak manusia Adam diciptakan Allah, maka ciri manusianya adalah kemampuan berfikir, kesanggupan menerima dan penyerap pengetahuan dari luar, berkomunikasi, berkehidupan sosial, beriman, berkesadaran ethis dan religius. Manusia pertama Adam dalam konsepsi Al-Qur'an mempunyai pengetahuan yang kreatif yang melebihi malaikat. Keunggulan ini dipakai oleh Allah untuk menenangkan Adam dalam kompetisinya dengan para malaikat, dan menjadikan Adam layak memperoleh penghormatan dari para malaikat. Kecuali Iblis yang menolak keputusan Allah ini karena kesombongan biologis dan rasialnya, dan sejak itu iblis muncul sebagai kekuatan anti manusia yang terus menerus berusaha menyesatkan manusia dari jalan kebenaran, dengan segala cara yang dapat dilakukan, termasuk mendayagunakan kelemahan manusia dalam mengendalikan "hawa nafsunya" sendiri. Konflik merupakan tantangan abadi bagi manusia dan yang menempatkan hidupnya sebagai perjuangan moral yang tidak berkesudahan.

Menurut Achmad Syauqi yang dikutip oleh Sahilun A. Natsir mengatakan dalam syairnya:

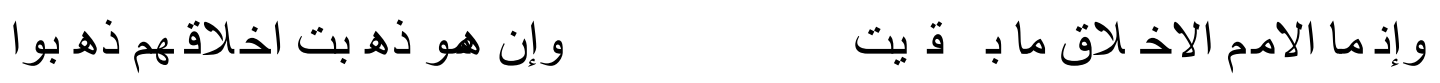

"Martabat suatu bangsa itu bergantung pada akhlaknya. Jika akhlaknya rusak, maka rusak binasa pulalah bangsa itu".

Pernyataan di atas jelaslah bahwa akhlak hendaknya selalu menjadi landasan bagi kehidupan manusia. Sebab kalau tidak demikian, maka kehancuran itu menimpa, baik bagi generasi sekarang maupun generasi yang akan datang. Dengan demikian pendidikan agama Islam mempunyai posisi yang penting, karena pendidikan agama sebagai sarana pembentukan dan pembangunan pondasi manusia Indonesia yang mempunyai nilai etik, moral, berkepribadian dilandasi dengan iman dan bertaqwa, dapat dijadikan sebagai pengendali dan dapat mengokohkan jiwa. Adanya kendali yang kokoh akan menghasilkan individu-individu yang berpegang kuat dengan Al-Qur'an dan Al-Hadits sebagai pegangan setiap pribadi yang berakhlakul karimah.

Dengan adanya pengembangan kualitas manusia juga dapat memperkokoh pemahaman dan keimanan agama Islam, bisa juga dengan meningkatkan ilmu pengetahuan dan teknologi 
$\int \begin{aligned} & \text { p-ISSN: } 2723-4703 \\ & \text { e-ISSN: - } \\ & \text { http://ejurnal.iaipd-nganjuk.ac.id/index.php/j-kis/ } \\ & \text { KURNALUNIKASI ISLAM }\end{aligned}$

yang dimiliki. Penguasaan iptek oleh umat Islam (salah satu aspek yang sangat menentukan kebesaran dan kemajuan suatu bangsa atau umat), dimaksudkan agar umat Islam bisa berperan di tengah-tengah kemajuan peradaban itu.

Manusia dibekali oleh Tuhan dengan beberapa potensi dasar yang sangat membantu dalam rangka mengembangkan kualitas sumber daya manusia. Potensi-potensi dasar yaitu Potensi jasmani (fisik), potensi nalar (akal/ratio), Potensi Hati Nurani (Qalbu). Dengan adanya potensi-potensi tersebut dalam diri manusia terdapat sejumlah potensi atau sumber daya yang harus dikembangkan agar dapat menjadi manusia yang dalam arti sesungguhnya. Oleh karena itu setiap orang harus berusaha mengembangkan potensi yang terdapat dalam dirinya, sebab tidak ada yang dapat merubah nasib seseorang kecuali dirinya sendiri. Sebagaimana firman Alloh swt dalam surat Ar-Ra'd ayat 11 yang berbunyi:

$$
\text { ي روا ماب ان فهم.... (ال رعد: 11)غي ىتح موقب امري غيال مللا نا..... }
$$

...Sesungguhnya Allah tidak merubah keadaan sesuatu kaum sehingga mereka merubah keadaan yang adapada dirinya sendiri.... (Q.S. Ar-Ra'd: 11)

Dari ayat diatas jelaslah bahwasanya Alloh SWT, menganjurkan untuk berusaha merubah kehidupan manusia dari kaum yang sebelumnya, agar lebih berguna bagi pembangunan bangsa dan agama.

Keutuhan pengembangan ketiga potensi dasar manusia tersebut akan memberikan kualitas manusia yang utuh pula. Disitulah pentingnya peranan agama, moral, kesehatan dan lingkungan hidup, disamping ilmu pengetahuan dan teknologi. Tapi sebaliknya, apabila pengembangan potensi dasar manusia tersebut tidak dilakukan secara berimbang dan harmoni, dampaknya mewujudkan hadirnya manusia-manusia pecah kepribadian dan krisis dimensi, kuat tapi bodoh, atau cerdas tapi jahat, atau etis tapi lemah.

\section{KESIMPULAN}

Peningkatan sumber daya manusia mendapatkan perhatian yang sangat besar, karena merupakan persyaratan untuk memacu pembangunan. Dan peningkatan sumber daya manusia membutuhkan penguasaan IPTEK tanpa mengesampingkan penguasaan IMTAQ. Dan manusia dalam pandangan Islam merupakan makhluk unggulan, yang membekali beberapa potensi, yaitu jasmani (fisik), potensi nalar (akal/ratio), potensi hati nurani (qalbu). Dengan demikian kualitas 
manusia akan terbentuk, Potensi-potensi tersebut harus dikembangkan dalam rangka pencapaian kompetensi-kompetensi yang memungkinkan manusia melakukan tugas esensialnya dalam hidup, yaitu "Ibadah kepada Tuhan" dan "Khalifah dari Tuhan". Dan keutuhan pengembangan ketiga potensi manusia tersebut akan memberikan kualitas manusia yang utuh. Disitulah peranan agama, moral, kesehatan dan lingkungan hidup, disamping ilmu pengetahuan dan teknologi. Tapi sebaliknya, apabila pengembangan potensi dasar manusia tersebut tidak dilakukan secara seimbang dan harmoni, dampaknya mewujudkan hadirnya manusia-manusia pecah kepribadian dan krisis dimensi, kuat tapi bodoh, atau cerdas tapi jahat, atau etis tapi lemah. Dengan demikian kualitas SDM pada intinya terletak pada kualitas ilmu dan akhlak, yang ditopang dengan kualitas ketrampilan yang memadai. Untuk dapat mencapai kualitas sumber daya manusia yang berkualitas dan dapat berkembang secara maksimal harus ada pembinaan melalui pendidikan baik itu pendidikan formal, informal, non formal.

Pengembangan kualitas manusia dengan jalan mengembangkan potensi-potensi atau sumber daya yang ada pada diri manusia agar dapat menjadi manusia yang dalam arti sesungguhnya. Pengembangan kualitas manusia itu bisa dengan memperkokoh pemahaman dan keimanan agama Islam, bisa juga dengan meningkatkan ilmu pengetahuan dan teknologi yang dimiliki. Penguasaan iptek oleh umat Islam (salah satu aspek yang sangat menentukan kebesaran dan kemajuan suatu bangsa atau umat), dimaksudkan agar umat Islam bisa berperan di tengahtengah kemajuan peradaban itu.

\section{DAFTAR PUSTAKA}

Ali, Yunasril. Urgensi Pendidikan dalam Meningkatkan Kualitas Sumber Daya Manusia Dilihat dari ajaran Islam, STAIN Kecinci: Jurnal Ilm iah "ISLAMIKA”, 1998

Ali, Zainuddin. Pendidikan Agama Islam, Jakarta: Bumi Aksara, 2007

Arikunto, Suharsimi. Prosedur Penelitian ; Suatu Pendekatan Praktek, edisi Revisi, Jakarta: Rineka Cipta, 1998

Arikunto, Suharsimi. Prosedur Penelitian Suatu Pendekatan, Jakarta: Bina Aksara, 2009

Azizy, Qodri. Melawan Globalisasi; Reinterpretasi Ajaran islam (Persiapan SDM terciptanya Masyarakat Madani), Yogyakarta: Pustaka Pelajar, 2004

Azra, Azyumardi. Pendidikan Islam, Jakarta: Logos, 2000

Dawam Rahardjo, Keluar dari Kemelut Pendidikan Nasional; Menjawab Tangtangan Kualitas Sumber daya Manusia Abad 21, Jakarta: PT Intermasa, 1997 
$\int \begin{aligned} & \text { p-ISSN: } 2723-4703 \\ & \text { e-ISSN: - } \\ & \text { http://ejurnal.iaipd-nganjuk.ac.id/index.php/j-kis/ } \\ & \text { KURNALUNIKASI ISLAM }\end{aligned}$

Departemen Pendidikan Nasional, Pedomen Penulisan Karya Ilmiah, Malang: Universitas Negeri Malang (UM), 2000

Hasan, Moh. Tholhah. Islam dan Masalah Sumber Daya Manusia, Jakarta: Lantabra Press, 2003

Langgulung, Hasan. Peralihan Paradigma Dalam Pendidikan Islam dan Sains Sosial, Jakarta: Gaya Media Pratama, 2002

Madjid, Nur Cholis. Islam Agama Kemanusiaan, Jakarta: Paramadina, 1995

Malayu, Manajemen Sumber Daya Manusia, Jakarta: Bumi Aksara, 2002

Marzuki, Metodologi Riset, Jakarta:BPFE, 1989

Matta, Anis. Membentuk Karakter Cara Islam, Jakarta: Al-I’tishom Cahaya Umat, 2003

Muhajir Noeng, Metodologi Penelitian Kualitatif: Telaah Positifistik, Rasionalistik, Realisme Metaphisik, Yogyakarat: Rake Sarasin, Cet. IV, 1999

Nata, Abuddin. Menejemen Pendidikan Mengatasi Kelemahan Pendidikan Islam di Indonesia, Jakarta: Kencana, 2003

Nata, M. Abuddin. Manajemen Pendidikan, Jakarta: Kencana, 2002

Sidi, Indra Jati. Menuju Masyarakat Belajar; mengagas paradigma Baru Pendidikan, Jakarta: Gaya Media Pratama, 2003

Sirozi, Muhammad. Agenda Strategis Pendidikan Islam, Yogyakarta: AKTIVITAS Group, 2004

Soejono dan Abdurrahman, Metode Penelitian: Suatu Pemikiran dan Penerapan, Jakarta: PT. Rineka Cipta, 2009

Soekarno, dkk, Sejarah danFilsafat Pendidikan Islam, Bandung, Angkasa, 1983

Syamsuddin, M. Din. Etika Agama dalam Membangun Masyarakat Madani, Jakarta: PT Logos Wacana Ilmu, 2002

Syamsudin,, M. Din. Etika Agama dalam Membangun Masyarakat Madani, Jakarta : Logos, 2002

Tulus, Magos, Manejemen Sumber Daya Manusia, Jakarta: PT Gramedia Pustaka Utama, 1992

Waloyo, Bambang. Penelitian Hukum dalam Praktek, Jakarta: Sinar Grafika, 1996

Zainuddin, Islam dan Fenomena Abad Modern, Tuluangagung: Jurnal Ilmiah Syari'ah, 2000 